\title{
Cointegration between Exchange Rate Volatility and Key Macroeconomic Fundamentals: Evidence from Nigeria
}

\author{
Edet Joshua Udoh $^{1 *}$, Sunday Brownson Akpan ${ }^{2}$, Daniel Etim John ${ }^{1}$, Inimfon Vincent Patrick ${ }^{2}$ \\ ${ }^{1}$ Department of Agricultural Economics and Extension, University of Uyo, Uyo, Nigeria \\ ${ }^{2}$ Department of Agricultural Economics \& Resources Management, Akwa Ibom State University, Mkpat-Enin, Nigeria \\ Email: *ej_udoh@hotmail.com
}

Received May 24, 2012; revised July 4, 2012; accepted August 6, 2012

\begin{abstract}
The study modelled the short run and long run impact of some macroeconomic fundamentals on the exchange rate volatility in Nigeria. Unit root test conducted on the specified time series showed that all series were integrated of order one. The short-run and long-run elasticities of exchange rate volatility with respect to some key macro-economic fundamentals were determined using the techniques of co-integration and error correction model estimation. The empirical results revealed that the coefficients of the total import, industrial capacity utilization rate, lending rate of commercial Banks, foreign private investment and liberalization policy period are significant in the long run. Whereas the coefficients of external reserves, inflation rate, interest rate, foreign private investment, total import and industrial capacity utilization rate were significant in the short run. The result advocated for appropriate short and long term policy packages that should focused on stabilization of the identified significant shifters of exchange rate volatility in the Nigeria's economy. Harmonization of transactions in the various foreign exchange markets in Nigeria should be a priority objective in the current exchange rate policy.
\end{abstract}

Keywords: Exchange Rate; Volatility; GARCH; Macroeconomic; Variables; Policies

\section{Introduction}

The late 1970s and early 1980s witnessed a period of unceasing macroeconomic decline in most developing countries as was evidenced by the stagnation of their economies and internal structural imbalances as well as severe external imbalances [1]. These problems seem to have been more severe in the Sub-Saharan African countries whose economies have been exposed to greater external and domestic economic shocks [2]. These crises necessitated fundamental changes to reduce distortions in their economies in the face of rising domestic and external pressures. One critical area of drastic change for most of these countries was their foreign exchange rate policy. It was believed that all or most of their currencies were over-valued due to the policy of fixed exchange rates which they adopted. In response to this distortions and imbalances in the economy, many Sub-Saharan Africa countries modified their exchange rate regimes to make them more flexible and responsive to the current global economic conditions [3]. Such modifications included steep devaluation, adoption of crawling peg regimes and

\footnotetext{
"Corresponding author.
}

the auctioning of available foreign exchange resources among others. "In broad terms, developing countries that adopted any form of flexible exchange rate system option were those suffering from severe balance of payments difficulties compounded by accumulated external payments arrears, who in addition lack official foreign exchange reserves needed to support a fixed exchange rate which has come under intense market pressure" [4].

Since independence, Nigeria like most developing countries in the Sub Saharan Africa has practiced a fixed system of exchange rate control until the radical change in 1986 when a more flexible exchange rate regime was introduced. Before the introduction of the Structural Adjustment Programme (SAP) in 1986, Nigeria's economy was characterized by serious internal structural distortions and external imbalances. These have been linked to the overvaluation of the naira and the collapse of international primary commodity market prices including that of oil, on which Nigeria was strongly dependent. Towards the end of 1985 to early 1986, the Nigerian government rather than continuing with the ad-hoc policy measures which had been tried in the past for economic recovery, decided to undertake a comprehensive structural adjust- 
ment, the bedrock of which was a more flexible foreign exchange rate system.

Frequent adjustments in exchange rate policy measures in Nigeria have been linked to the prevalence of high degree of volatility in exchange rate movement which policy makers believed is capable of distorting activities in other sectors of the economy [1]. However, most literature on the issue has presented conflicting evidences pertaining to the relationship between exchange rate volatility and fluctuation in some key macroeconomic fundamentals in Nigeria. Evidence of macroeconomic variables fluctuation across various policy regimes in Nigeria abound in the literature. For instance, the inflation rate had shown a wide variability across exchange rate policy periods in Nigeria (CBN, 2010 and Table 1). In a similar way, index of agricultural production, the external reserve, real GDP per capita and real foreign private investment in the manufacturing sector have exhibited an undulating trend across various exchange rate policy periods in Nigeria (Table 1). Although many factors might have combined to explain the general adverse development in some key macroeconomic variables in Nigeria, the exchange rate policy has frequently been identified as a major contributor [1]. Theoretically, it has been recognized that the maintenance of an appropriate exchange rate regime is a necessity but not a sufficient condition for the achievement of desired macroeconomic objectives. The stability and proper alignment of the exchange rates are absolutely essential to the restoration of growth in the tradable goods sector and indeed, the aggregate economy [5-8].

Exchange rate fluctuations are likely in turn to deter- mine economic performance. In judging the desirability of exchange rate fluctuation, it becomes therefore necessary to evaluate the contribution of some key macroeconomic fundamentals in the economy to such fluctuation. A depreciation of the domestic currency may stimulate economic activity through the initial increase in the price of foreign goods relative to home goods. By increasing the international competitiveness of domestic industries, exchange rate depreciation diverts spending from foreign goods to domestic goods. While fixed exchange rates reduce uncertainty and transaction costs, these benefits may be outweighed by increased output volatility due to sticky prices and increased international interdependence. Foreign exchange market developments have cost implications for the households, firms and the state. [9] Showed that exchange rate volatility have real economic costs that affect price stability, firm profitability and a country's stability. Many economists argue that exchange rate stability facilitates production activities and economic growth. This group of economists also supports the view that misalignment in real exchange rate could distort production activities and consequently hinders exports growth and generates macroeconomic instability [10]. Exchange rate policy guides investors on the best way they can strike a balance between their trading partners, and investing at home or abroad [11]. The widening premium between the official and parallel exchange market has lead to precarious operating environment evidence by insufficient foreign and domestic investment in Nigeria [12].

With the exception of a brief period of confusion in exchange rate policy formulation in the country (i.e.

Table 1. Macroeconomic variable fluctuations in various policy regimes in Nigeria.

\begin{tabular}{|c|c|c|c|c|c|c|c|}
\hline \multirow{2}{*}{ Indicator } & \multicolumn{7}{|c|}{ Policy periods } \\
\hline & $1970-1975$ & $1976-1980$ & $1981-1985$ & 1986-1990 & $1991-1995$ & $1996-2000$ & $2001-2005$ \\
\hline \multicolumn{8}{|l|}{ Mean macroeconomic variable indicator } \\
\hline Inflation rate $(\%)$ & 14.3 & 13.0 & 19.4 & 20.5 & 48.9 & 12.3 & 15.7 \\
\hline Official Exchange rate $(\mathrm{N} / \mathrm{\$})$ & 0.66 & 0.69 & 0.77 & 5.90 & 19.16 & 54.78 & 127.84 \\
\hline External Reserve $(\$ \mathrm{~b})$ & 1.19 & 3.06 & 1.40 & 11.98 & 39.2 & 361.6 & 1869.7 \\
\hline Index of Energy Consumption $(1985=100)$ & 26.3 & 64.6 & 122.8 & 95.6 & 95.7 & 83.3 & 167.4 \\
\hline Real GDP per capita $(\mathbb{N} /$ person) $(1985=100)$ & 177.2 & 735 & 3.25 & 962 & 674 & 547 & 819 \\
\hline Real FPI in Manu. and Processing ( $\mathrm{Nb}$ ) & 2.79 & 3.17 & 2.74 & 2.20 & 1.53 & 1.09 & 1.26 \\
\hline Index of Agricultural Production $(1990=100)$ & 65.62 & 56.44 & 58.74 & 79.20 & 121.6 & 141.5 & 158.2 \\
\hline Index of Manufacturing Production $(1985=100)$ & 32.85 & 75.42 & 105.7 & 135.4 & 154.7 & 137.2 & 145.6 \\
\hline Non oil export (\$m) & 358.4 & 574.9 & 328.4 & 2335.1 & 8468.3 & 26175.4 & 87356.4 \\
\hline
\end{tabular}

Source: Computed by authors, data from central bank of Nigeria statistical bulletin (2008) and World Bank publications on developing countries (2007). 
1972-1974), four distinct regimes of exchange rate were observed between 1960 and 2010: the fixed rate regime of 1960-1970, the adjustable peg regime of 1974-1978, the managed float regime of 1978-1985 and the flexible rate regime of 1986 - till date. Whereas the first three regimes have been criticized for generating relatively greater exchange rate misalignment in the country, the last regime has been noted for its unprecedented level of volatile exchange rates [4,13].

Therefore, given the above mixed consequences of increasing disparity in exchange rate volatility, it becomes relevant to investigate the causal relationship between exchange rate volatility and some key macroeconomic variables in the Nigeria's economy. The knowledge of such correlation could reduce uncertainty and risk syndrome prevalence among investors in the country and foster the achievement of the overall economic objectives of the federal government. Therefore, the study specifically determined macroeconomic factors which influenced exchange rate volatility from 1968 to 2010 in Nigeria.

\section{Theoretical Framework and Literature Review}

In modelling the impact of macroeconomic variables on exchange rate volatility in Nigeria, we toke special interest in the model developed by [14]. This approach is typical of a two-country model of international trade. It assumes that demand for a country's exports depends on real foreign income and relative (foreign) prices as follows:

$$
X^{d}=f\left(Y^{f}, P^{f} x, Q\right)
$$

where $X^{d}$ denotes the demand for exports of a country;
$Y^{f}$ is the level of real foreign income; $P^{f} x$ is the relative prices of exportable abroad; $P^{f} x=P_{E} / E P^{f} ; P_{E}$ is the price of exportable in domestic currency; $E$ is the nominal exchange rate defined as amount of local currency per unit of foreign currency; and $P^{f}$ is the foreign price level. $Q$ is the real exchange rate. The supply of exports depends on domestic relative prices, exchange rate volatility and the terms of trade as follows:

$$
X^{s}=f\left(P^{d} x, V, T O T\right)
$$

where $X^{s}$ is supply of exports; $P^{d} x=\left(P_{E} / P\right)$ is the domestic relative price of exportable; $P$ is the domestic price level; $V$ is exchange rate volatility; and TOT denotes the terms of trade. Expressing these functions in $\log$ form (upper cases denote natural logs) except for $V$, which can take negative values, Equations (1) and (2) become:

$$
X^{d}=\alpha_{0}+\alpha_{1} Y^{f}+\alpha_{2} P^{f} x+\alpha_{3} Q+\mu_{1}
$$

And,

$$
X^{s}=\beta_{0}+\beta_{1} P^{d} x+\beta_{2} V+\beta_{3} T O T+\mu_{2}
$$

where $\mu_{1}$ and $\mu_{2}$ are uncorrelated error terms. Assuming equilibrium in the export market (i.e.,

$X^{s}=X^{d}=x$ ) and solving for price at equilibrium (i.e., $P^{f} x=P^{d} x=P_{x}$ ) from Equations (3) and (4) we get:

$$
\begin{gathered}
P_{x}\left(\alpha_{2}-\beta_{1}\right)=\beta_{0}-\alpha_{0}+\beta_{2} V+\beta_{3} T O T-\alpha_{1} Y^{f}-\alpha_{3} Q \\
P_{x}=\frac{\beta_{0}-\alpha_{0}+\beta_{2} V+\beta_{3} T O T-\alpha_{1} Y^{f}-\alpha_{3} Q}{\left(\alpha_{2}-\beta_{1}\right)}
\end{gathered}
$$

Substituting Equation (6) into Equation (4) where $P^{d} x=P_{x}$ and solving for $V$;

$$
\begin{aligned}
& X^{s}=\beta_{0}+\frac{\beta_{1}\left\{\left(\beta_{0}-\alpha_{0}\right)+\left(\beta_{2} V\right)+\left(\beta_{3} T O T\right)-\left(\alpha_{1} Y^{f}\right)-\left(\alpha_{3} Q\right)\right\}}{\left(\alpha_{2}-\beta_{1}\right)}+\beta_{2} V+\beta_{3} T_{O} \\
& X^{s}=\beta_{0}+\frac{\left\{\beta_{1} \beta_{2} V+\beta_{1} \beta_{0}-\beta_{1} \alpha_{0}+\beta_{1} \beta_{3} T O T-\beta_{1} \alpha_{1} Y^{f}-\beta_{1} \alpha_{3} Q\right\}}{\left(\alpha_{2}-\beta_{1}\right)}+\beta_{2} V+\beta_{3} T O T_{2} \\
& X^{s}\left(\alpha_{2}-\beta_{1}\right)=\beta_{0}+\beta_{1} \beta_{0}-\beta_{1} \alpha_{0}+V\left(\beta_{1} \beta_{2}+\beta_{2}\right)+T O T\left(\beta_{1} \beta_{2}+\beta_{3}\right)-\beta_{1} \alpha_{1} Y^{f}-\beta_{1} \alpha_{3} Q \\
& V\left(\beta_{1} \beta_{2}+\beta_{2}\right)=X^{s}\left(\alpha_{2}-\beta_{1}\right)-\beta_{0}-\beta_{1} \beta_{0}+\beta_{1} \alpha_{0}-T O T\left(\beta_{1} \beta_{2}+\beta_{3}\right)+\beta_{1} \alpha_{1} Y^{f}+\beta_{1} \alpha_{3} Q \\
& V=\frac{\left(\beta_{1} \alpha_{0}-\beta_{0}-\beta_{1} \beta_{0}\right)+X^{s}\left(\alpha_{2}-\beta_{1}\right)-T O T\left(\beta_{1} \beta_{2}+\beta_{3}\right)+\beta_{1} \alpha_{1} Y^{f}+\beta_{1} \alpha_{3} Q}{\left(\beta_{1} \beta_{2}+\beta_{2}\right)}
\end{aligned}
$$

Equation (11) shows that a country's exchange rate volatility depends linearly on the foreign (trading partners') real income, real exchange rate, terms of trade and the level of import and export. The system of coefficients and sign attached to each variable represent the elastic- ities and direction of effect of the respective variables on exchange rate volatility. In a similar way many macroeconomics variables could be incorporated into the model to investigate their relationship with the exchange rate volatility. 


\subsection{Measuring Exchange Rate Volatility}

\section{Generalized Autoregressive Conditional} Heteroscedasticity (GARCH) Technique

The GARCH $(1,1)$ model was used to generate nominal exchange rate volatility for the study. It is summarized as follows:

$$
\begin{gathered}
\log Y=\alpha_{0}+\alpha_{1} \log Y_{t-1}+\epsilon_{t} \text { where } \epsilon_{t} \sim \text { Niid } N\left(0, \delta^{2}\right) \\
h_{t}=\beta_{0}+\beta_{1} \epsilon_{t-1}^{2}+\beta_{2} h_{t-1}
\end{gathered}
$$

Equation (12) is the mean equation from which the error term $\varepsilon_{t}$ was derived. $\left(h_{t}\right)$ is a conditional variance of $\varepsilon_{t}$ and a proxy of exchange rate volatility while $\beta_{0}>0, \beta_{1} \geq 0, \beta_{2} \geq 0$ Equation (13) shows that the conditional variance is explained by past shocks or volatility (ARCH term) and past variances (the GARCH term). Equation (13) will be stationary if the persistent of volatility shocks, $\sum \beta_{0}+\sum \beta_{1}$ is lesser than 1 and in the case it comes much closer to 1 , volatility shocks will be much more persistent. As the sum of $\alpha$ and $\beta$ becomes close to unity, shocks die out rather slowly [15]. The normality assumption of the error was adopted in the study.

\subsection{Empirical Review of Related Literature}

There is no consensus in the empirical literature concerning the factors that influenced exchange rate volatileity. According to [16], real exchange rate volatility is due to slow adjustment of commodity prices and rapid response of nominal exchange rates to exogenous shocks. [17] used aggregate data for the US, Germany, France, Japan and UK and finds mixed evidence regarding the effect of exchange rate volatility on import demand. [18] found similarly mixed results regarding the impact of exchange rate volatility on US import demand using bilateral time series for the major trading partners of the USA. [19] estimated the short- and long-run influence of exchange-rate volatility on the import flows of the United States, in the generalized floating exchange-rate period. He discovered a significant long and short-run negative effect of exchange-rate volatility on the volume of imports. [20] estimated the long run relationship between imports and exchange rate volatility in G-7 countries, during the quarterly period $1973: 2$ to $1995: 1$. They found that exchange rate volatility has a significant negative effect on the volume of imports of G-7, countries whereas for Canada, it is positive and significant. [21] in their empirical work revealed that exchange rate volatileity has no effect on Pakistan import in the long run whereas a significant effect was obtained in the short run. [22] analyzed the effect of real exchange rates on output for twenty eight devaluation experiences in developing countries using a regression framework. He observed that depreciation of the level of the real exchange rate reduced the output. [23] estimated a six-variable VARmoney supply, domestic price level, exchange rate index, foreign price index, real output, and the rate of interest - in an attempt to explain the inflation movement in Kenya. He observed that the rate of inflation and exchange rate explained each other.

[24] reported that positive shocks to the rate of exchange rate depreciation significantly reduced credit availability with a negative impact on the output. [25] utilized a five-variable VAR model-money, exchange rate, wages, prices, and income - to examine the sources of acceleration of inflation in Argentina, Brazil, and Israel. He concluded that among other key factors, exchange rate movements explained inflation in the three countries. [26] in Colombia observed that exchange rates did not play an important role in explaining the variation in inflation.

Empirical supports for domestic monetary policy as a potential source of real exchange rate variability is provided by $[27,28]$. Exchange rate volatility is not regime neutral. The switch to flexible exchange rate system resulted in significant increase in real exchange rate volatility (see [29-31]. Hviding et al. [32,33] provided evidence on the relationship between international reserves and real exchange rate volatility and established that a higher international reserve has a negative effect on exchange rate volatility. Greater variability in real productivity shocks usually proxied by variability in the rate of growth of real GDP results in higher exchange rate variability [34,35], applying two different econometric approaches - a theoretical vector autoregression and a structural production function-concluded that the net effect of a decline in the value of the dollar is a temporary increase in inflation and real output, followed by a permanent reduction in output and level of real wages. It was explicitly concluded that exchange rate volatility is a major factor for the upsurge of inflation [36] in Uganda, [37] in South America; [38] in Africa; [26] in Colombia; [33] in Nigeria and South Africa and [39] in Nigeria). Also [39,40] and [33] provided evidence of negative relationship between exchange rate volatility and foreign direct investment in African countries.

\section{Research Methodology}

\subsection{Study Area and Data Source}

The study was conducted in Nigeria; the country is situated on the Gulf of Guinea in the sub Saharan Africa. Nigeria lies between $4^{\circ}$ and $14^{\circ}$ north of the equator and between longitude $3^{\circ}$ and $15^{\circ}$ east of the Greenwich. Nigeria has a total land area of $923,768.622 \mathrm{~km}^{2}$ with 853 $\mathrm{km}$ of coastline along the northern edge of the Gulf of Guinea (98.3 million hectares) and a population of over 140 million [41]. Secondary data derived from publica- 
tions of Central Bank of Nigeria (CBN), National Bureau of Statistics, and Federal Ministry of Finance was used in the analysis. Data covered the period 1968 to 2010.

\subsection{Analytical Techniques}

The empirical models were specified based on the specific objectives of the study.

$$
\begin{aligned}
h_{t}= & \delta_{0}+\delta_{1} \operatorname{Ln} T I M_{t}+\delta_{2} \operatorname{Ln} E X R_{t}+\delta_{3} \operatorname{Ln} P G D P_{t} \\
& +\delta_{4} \operatorname{Ln} C U R_{t}+\delta_{5} \operatorname{Ln} I N F L_{t}+\delta_{6} \operatorname{Ln} A G R I_{t} \\
& +\delta_{7} \operatorname{Ln} E X D_{t}+\delta_{8} \operatorname{Ln} I N T E R_{t}+\delta_{9} \operatorname{Ln} F P I_{t} \\
& +\delta_{10} \operatorname{Ln} h_{t-1}+\delta_{11} \text { Dummy }+U_{t}
\end{aligned}
$$

where; $h_{t}=$ Exchange rate volatility, $T I M_{t}=$ real value of total imports $(\AA \mathrm{m}), E X R_{t}=$ external reserves as a ratio of GDP, $I N F L_{t}=$ inflation rate $(\%), P G D P_{t}=$ growth rate in real per capita GDP as a proxy of aggregate demand shock ( $\mathrm{Nm} /$ person), $C U R_{t}=$ industry's capacity utilizetion rate $(\%), E X D_{t}=$ external debt as a ratio of $G D P$, $A G R I=$ index of agricultural production; INTERt $=$ interest rate (lending rate); $F P I_{t}=$ real value of foreign

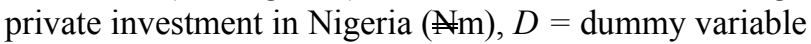
which takes the value 1 during liberalization period (1986-2010), and 0 otherwise (1970-1985), $U_{t}=$ stochastic error term and $U_{t} \sim \operatorname{IID}\left(0, \delta_{U}^{2}\right)$.

\section{Results and Discussion}

\subsection{Unit Root Test}

In time series analysis, stationarity of the series is examined by unit root tests. One of the most commonly used tests in literature to ascertain the stationarity level of series are ADF test developed by Dickey and Fuller in (1979) and ADF-GLS unit root test developed by Elliott, Rothenberg and Stock in (1996) which is an improvement of the original ADF test. These two tests were used in this study for determining the stationarity level of series. PC-Give 10 and gretl econometric softwares were used to carry out the tests and the result is presented in Table 2. The result for both ADF and ADF-GLS unit root tests show that all the specified variables were non stationary at levels but stationary at the first difference. The result implies that the time series should be tested for the existence of a cointegration $[42,43]$.

\subsection{Cointegration Test}

The concept of co-integration as developed by Granger (1981) involved the determination of the static or longrun associations among non-stationary time series. The pre-condition for applying the standard procedure of the co-integration tests to any series is that the variables in consideration must be integrated of the same order or non-stationary individually. The study applied the Engle and Granger two-step technique and Johansen cointegra- tion approach to examine cointegration relationship among time series.

The result of the Engle and Granger two-step technique of the cointegration regression and the stationarity tests for the residual (ECM) generated in Equation (15) is presented in Table 2. The results show that at the 1\% probability level of significance, the Engle-Granger cointegration tests reject the null hypothesis of no cointegration. Hence, there exists a long run equilibrium relationship between the exchange rate volatility and some major macroeconomic variables in Nigeria. For the Johansen cointegration approach, the trace and maximum eigenvalue test statistics were significant at various rank levels. The result as presented in Table $\mathbf{3}$ means that the calculated trace test and maximum eigenvalue test statistics are greater than the critical values at $10 \%, 5 \%$ and $1 \%$ probability levels. This implies that there is cointegration relationship among the specified variables. Table 4 presents the result of the long run equation of exchange rate volatility in Nigeria as specified in Equation (15).

\subsection{Optimal Lag-Length for Cointegrating Variables}

The following information criteria were used to select appropriate lag length for the cointegrating series: there are Akaike criterion (AIC), Schwarz Bayesian criterion (BIC) and Hannan-Quinn criterion (HQC). The test result as shown in Table 5 reveals that the optimum lag length appropriate for the specified variables is at the second lag indicated by the asterisks among the information criteria. This means that in generating the short run dynamic model for the exchange rate volatility in Nigeria, the optimum lag length of time series should be 2 in order to obtain a more interpretable parsimonious ECM model.

\subsection{Error Correction Model for Exchange Rate Volatility in Nigeria}

Following the Granger Representation Theorem, we specified the ECM model for the cointegrating series in the study. The primary reason for estimating the ECM model is to capture the dynamics in the exchange rate volatility equation in the short-run and to identify the speed of adjustment as a response to departures from the long-run equilibrium. The general specification of the ECM that was estimated for the exchange rate volatility in Nigeria is shown below:

$$
\begin{aligned}
\Delta h_{t}= & \delta_{0}+\delta_{1} \operatorname{Ln} T_{I M_{t-1}}+\delta_{2} \operatorname{Ln} E X R_{t-1}+\delta_{3} \operatorname{Ln} P G D P_{t} \\
& +\delta_{4} \operatorname{Ln} C U R_{t}+\delta_{5} \operatorname{Ln} I_{t-1}+\delta_{6} \operatorname{Ln} A G R I_{t} \\
& +\delta_{7} \operatorname{Ln} E X D_{t}+\delta_{8} \operatorname{Ln} I_{T T E R_{t}}+\delta_{9} \operatorname{Ln} F P I_{t-2} \\
& +\delta_{10} \operatorname{Ln} h_{t-1}+\delta_{11} \text { Dummy }+\delta E C M_{t-1}+U_{t}
\end{aligned}
$$

The variables are as defined previously in Equation 
Table 2. Result of the unit root test for variables used in the analysis.

\begin{tabular}{|c|c|c|c|c|c|c|c|c|c|c|c|c|}
\hline \multirow{3}{*}{$\begin{array}{c}\text { Logged } \\
\text { Variables }\end{array}$} & \multicolumn{6}{|c|}{ Augmented Dicker Fuller Test for unit root } & \multicolumn{6}{|c|}{ ADF-GLS Test for unit root } \\
\hline & \multicolumn{3}{|c|}{ With Trend } & \multicolumn{3}{|c|}{ Without Trend } & \multicolumn{3}{|c|}{ With Trend } & \multicolumn{3}{|c|}{ Without Trend } \\
\hline & Level & 1 st diff. & OOI & Level & 1 st diff. & OOI & Level & 1st diff. & OOI & Level & 1 st diff. & OOI \\
\hline $\mathrm{h}$ & -0.996 & $-4.31^{*}$ & $1(1)$ & -1.050 & $-4.08^{*}$ & $1(1)$ & -1.082 & $-4.19^{*}$ & $1(1)$ & -1.094 & $-4.11^{*}$ & $1(1)$ \\
\hline TIM & -2.017 & $-7.08^{*}$ & $1(1)$ & -0.751 & $-7.15^{*}$ & $1(1)$ & -2.097 & $-7.26^{*}$ & $1(1)$ & 1.168 & $-7.24^{*}$ & $1(1)$ \\
\hline EXR & -3.178 & $-6.93^{*}$ & $1(1)$ & -2.158 & $-7.01^{*}$ & $1(1)$ & -3.212 & $-7.07^{*}$ & $1(1)$ & -2.050 & $-6.89^{*}$ & $1(1)$ \\
\hline PGDP & -1.549 & $-6.05^{*}$ & $1(1)$ & -2.106 & $-5.85^{*}$ & $1(1)$ & -1.439 & $-6.09^{*}$ & $1(1)$ & -0.301 & $-5.85^{*}$ & $1(1)$ \\
\hline CUR & -1.550 & $-5.05^{*}$ & $1(1)$ & -1.087 & $-5.11^{*}$ & $1(1)$ & -1.592 & $-5.18^{*}$ & $1(1)$ & -0.686 & $-5.18^{*}$ & $1(1)$ \\
\hline INFL & -4.096 & $-7.79^{*}$ & $1(1)$ & -3.572 & $-7.90^{*}$ & $1(1)$ & -3.535 & $-6.60^{*}$ & $1(1)$ & -2.544 & $-4.70^{*}$ & $1(1)$ \\
\hline EXD & -1.008 & $-6.02^{*}$ & $1(1)$ & -1.360 & $-5.92^{*}$ & $1(1)$ & -1.275 & $-6.13^{*}$ & 1(1) & -1.369 & $-5.99^{*}$ & $1(1)$ \\
\hline FPI & -1.888 & $-5.25^{*}$ & $1(1)$ & -0.268 & $-5.34^{*}$ & $1(1)$ & -1.920 & $-5.03^{*}$ & $1(1)$ & 1.515 & $-4.19^{*}$ & $1(1)$ \\
\hline INTER & -1.975 & $-8.91^{*}$ & $1(1)$ & -1.586 & $-8.93^{*}$ & $1(1)$ & -2.108 & $-9.10^{*}$ & $1(1)$ & -1.153 & $-9.01^{*}$ & $1(1)$ \\
\hline AGRI & -2.806 & $-6.44^{*}$ & $1(1)$ & -0.109 & $-6.31^{*}$ & $1(1)$ & -1.679 & $-6.52^{*}$ & $1(1)$ & -0.099 & $-5.61^{*}$ & $1(1)$ \\
\hline ECM & $-4.922^{*}$ & & $1(0)$ & $-4.986^{*}$ & & $1(0)$ & $-4.867^{*}$ & - & $1(0)$ & $-4.786^{*}$ & & $1(0)$ \\
\hline \multicolumn{13}{|c|}{ Critical Values defined at $1 \%$ significance level } \\
\hline $\mathrm{CV}$ & -4.19 & -4.20 & & -3.60 & -3.60 & & -3.77 & -3.77 & & -3.77 & -3.77 & \\
\hline
\end{tabular}

Note: OOI means order of integration. Critical value (CV) is defined at $1 \%$ significant level and asterisk ${ }^{*}$ represents $1 \%$ significance level. Variables are as defined in Equations (15).

Table 3. Results of johansen cointegration test (unrestricted constant).

\begin{tabular}{cccccc}
\hline Rank & Eigen value & Trace Test & P-value & Lmax. Test & P-value \\
\hline 0 & 0.9083 & 404.60 & 0.000 & 97.962 & 0.000 \\
1 & 0.888 & 306.64 & 0.000 & 89.774 & 0.000 \\
2 & 0.780 & 216.86 & 0.000 & 62.081 & 0.002 \\
3 & 0.667 & 154.78 & 0.000 & 45.084 & 0.063 \\
4 & 0.593 & 109.70 & 0.003 & 36.854 & 0.110 \\
5 & 0.467 & 72.84 & 0.026 & 25.797 & 0.345 \\
7 & 0.421 & 47.05 & 0.058 & 22.387 & 0.207 \\
8 & 0.257 & 24.66 & 0.178 & 12.204 & 0.541 \\
9 & 0.227 & 12.46 & 0.137 & 10.541 & 0.182 \\
\hline
\end{tabular}

Note: The null hypothesis of no cointegration is rejected at $1 \%$ probability level.

(15) and the coefficient $(\delta)$ of the $E C M t_{-1}$ measures the deviations from the long-run equilibrium in period $\left(t_{-1}\right)$. In order to obtain a parsimonious dynamic ECM for the exchange rate volatility equation, the study adopted Hendry's (1995) approach in which an over parameterized model is initially estimated and then gradually reduced by eliminating insignificant lagged variables until a more interpretable and parsimonious model is obtained.
The result of the exercise is presented in Table 6.

The slope coefficient of the error correction term is negative and statistically significant at $1 \%$ probability level. The result validates the existence of a long-run equilibrium relationship among the time series in the exchange rate volatility equation, and also indicates that the exchange rate is sensitive to the departure from it equilibrium value in the previous periods. The slope co- 
Table 4. Long-run equation of exchange rate volatility in Nigeria.

\begin{tabular}{|c|c|c|c|c|c|}
\hline \multicolumn{2}{|c|}{ Variables } & Coefficient & \multicolumn{2}{|c|}{ Std. error } & t-value \\
\hline \multicolumn{2}{|c|}{ Constant } & -8.733 & \multicolumn{2}{|l|}{2.743} & $-3.184^{* * *}$ \\
\hline \multicolumn{2}{|c|}{$\operatorname{Ln} T I M_{t}$} & -0.468 & \multicolumn{2}{|l|}{0.177} & $2.645^{* * *}$ \\
\hline \multicolumn{2}{|c|}{$\operatorname{Ln} E X R_{t}$} & -0.005 & \multicolumn{2}{|l|}{0.137} & -0.038 \\
\hline \multicolumn{2}{|c|}{$\operatorname{Ln} P G D P_{t}$} & 0.0131 & \multicolumn{2}{|l|}{0.013} & 1.023 \\
\hline \multicolumn{2}{|c|}{$\mathrm{LnCUR}_{t}$} & 1.889 & \multicolumn{2}{|l|}{0.438} & $4.314^{* * *}$ \\
\hline \multicolumn{2}{|c|}{$\operatorname{Ln} I N F L_{t}$} & -0.084 & \multicolumn{2}{|l|}{0.095} & -0.882 \\
\hline \multicolumn{2}{|c|}{$\operatorname{Ln} A G R I_{t}$} & -0.231 & \multicolumn{2}{|l|}{0.466} & -0.496 \\
\hline \multicolumn{2}{|c|}{$\operatorname{Ln} E X D_{t}$} & 0.085 & \multicolumn{2}{|l|}{0.079} & 1.063 \\
\hline \multicolumn{2}{|c|}{$\operatorname{Ln} I N T E R_{t}$} & -1.483 & \multicolumn{2}{|l|}{0.509} & $-2.916^{* * *}$ \\
\hline \multicolumn{2}{|c|}{$\operatorname{Ln} F P I_{t}$} & 1.354 & \multicolumn{2}{|l|}{0.24} & $5.470^{* * *}$ \\
\hline \multicolumn{2}{|c|}{ Policy } & -0.985 & \multicolumn{2}{|l|}{0.501} & $-1.965^{*}$ \\
\hline \multirow{2}{*}{\multicolumn{6}{|c|}{$\begin{array}{l}\mathrm{R}^{2}=0.863 ; \text { Log-likelihood }=-20.95 ; \text { Akaike Criterion }=63.91 ; \text { Han } \\
\text { nan-Quinn }=71.05 ; \mathrm{DW}-\mathrm{test}=1.52 ; \mathrm{F}-\text {-statistic }=20.11^{* * *} ; \text { Schwarz Crite- } \\
\text { rion }=83.28 ; \text { RESET test }=5.09^{* *} \text {. Note: Asterisks }{ }^{*} \text { and }{ }^{* * *} \text { represent } 10 \% \\
\text { and } 1 \% \text { significance levels respect- tively. Variables are as defined in Equa- } \\
\text { tion (15). } \\
\text { Table 5. Optimal lag length of variables used in the analy- } \\
\text { sis. }\end{array}$}} \\
\hline & & & & & \\
\hline Lags & loglike & $\mathrm{p}(\mathrm{LR})$ & AIC & BIS & HQC \\
\hline 1 & -8.4613 & 0.0000 & 0.9731 & 1.4375 & 1.1410 \\
\hline 2 & -5.7030 & 0.0188 & $0.8852^{*}$ & $1.3918^{*}$ & $1.0683^{*}$ \\
\hline 3 & -5.3517 & 0.4019 & 0.9176 & 1.4665 & 1.1160 \\
\hline
\end{tabular}

Note: Asterisk means optimum lag length.

efficient of the error correction term (0.7931) represents the speed of adjustment and also is consistent with the hypothesis of convergence towards the long-run equilibrium once the exchange rate volatility equation is shocked. The $E C M_{t}$ value of 0.7931 suggests that in the absence of variation in the specified macroeconomic variables in the short run, that about 79.31 percent of the divergence between actual and equilibrium value of the exchange rate volatility is corrected annually in Nigeria.

The diagnostic test for the ECM model revealed $\mathrm{R}^{2}$ value of 0.6847 which means that the specified explanatory time series explained about $68.47 \%$ of the adjusted total variations in the value of the exchange rate volatility in Nigeria. The F-statistic of 4.89 is significant at 1\% probability level, indicating that the $\mathrm{R}^{2}$ is significant and this implies that the equation has goodness of fit. The Durbin-Watson value of 2.22 indicates that autocorrelation is not a serious problem.

The exchange rate volatility in the ECM model has an
Table 6. ECM estimates of the exchange rate volatility equation in Nigeria.

\begin{tabular}{cccc}
\hline Variables & Coefficient & Std. error & t-value \\
\hline Constant & 0.1329 & 0.0858 & 1.55 \\
$\Delta \operatorname{Ln} h_{t-1}$ & -0.4386 & 0.1208 & $-3.63^{* * *}$ \\
$\Delta \operatorname{Ln} E X R_{t-1}$ & -0.2033 & 0.0746 & $-2.73^{* *}$ \\
$\Delta \operatorname{Ln} P G D P_{t}$ & 0.0061 & 0.0056 & -1.09 \\
$\Delta \operatorname{Ln} I N F L_{t-1}$ & -0.1457 & 0.0604 & $2.41^{* *}$ \\
$\Delta \operatorname{Ln} A G R I_{t}$ & -0.4702 & 0.6752 & -0.70 \\
$\Delta \operatorname{Ln} E X D T_{t}$ & 0.0317 & 0.0617 & 0.52 \\
$\Delta \operatorname{Ln} I N T E R_{t}$ & -1.1204 & 0.2460 & $-4.55^{* * *}$ \\
$\Delta \operatorname{Ln} F P I_{t-2}$ & -0.5741 & 0.2442 & $-2.35^{* *}$ \\
$\Delta \operatorname{Ln} T I M_{t-1}$ & -0.2231 & 0.0556 & $-4.01^{* * *}$ \\
$\Delta \operatorname{LnCUR}_{t}$ & 0.9754 & 0.4978 & $1.96^{*}$ \\
$\operatorname{Dummy}$ & 0.1169 & 0.1080 & 1.08 \\
$E C C M_{t-1}$ & -0.7931 & 0.1496 & $-5.30^{* * *}$ \\
\hline
\end{tabular}

$\mathrm{R}^{2}=0.685$; F-statistic $=4.89^{* * *} ;$ Hanna-Quinn $=30.49$; Adjusted $\mathrm{R}^{2}=0.545$; Schwarz Criterion $=44.52$; Akaike Criterion $=22.56$; Log-likelihood $=$ 1.720 ; RESET test $=0.0527$; rho $=-0.379 \mathrm{DW}$ - test $=2.22$; Normality test $=18.041^{* * *}$. Note: Asterisks ${ }^{*}{ }^{* *}$ and ${ }^{* * *}$ represent $10 \%, 5 \%$ and $1 \%$ significance levels respectively. Variables are as defined in Equation (15).

inelastic relationship with the external reserves in Nigeria. This means that in the short run, increase in the external reserves would lead to decrease in exchange rate volatileity. In the long run model, the relationship is neutral. The result is plausible in the Nigeria case, because in recent years the country's external reserves has increase tremendously thereby stabilizing some domestic macroeconomic variables and promoting positive growth rate in the economy. The finding is similar to the empirical results reported by [33] for Nigeria and South Africa and [32] in Zimbabwe.

In the short run, the slope coefficient of inflation has a significant (at $5 \%$ level) negative correlation with the nominal exchange rate volatility in Nigeria. The result implies that increase in the inflation reduces the tendency of increase exchange rate volatility in Nigeria. The result might be explained by the fact that increase in inflation would constrain cash circulation and this would reduce activities in the foreign exchange market. Contrary in the long run, the impact of inflation on exchange rate volatility becomes neutral probably due to the learning process or adaptation to the economy process by the investors. The finding agrees with the results reported by [36] in Uganda, [37] in South America; [38] in Africa; [26] in Colombia; [33] in Nigeria and South Africa and [39] in Nigeria [33] in Nigeria and South Africa. 
The result also revealed that exchange rate volatility has a significant negative elastic association with the lending interest rate of commercial banks in both short and long run exchange rate volatility models in Nigeria. Elastic relationship implies that $1 \%$ change in exchange rate volatility would result in a less than equivalent $1 \%$ change in interest rate in both periods. However the negative association between exchange rate volatility and interest rate could be attributed to the frequent intervenetion of the Central Bank of Nigeria on the operations of commercial banks in the country.

In the short run, foreign private investment (FPI) reduces exchange rate volatility in Nigeria. The reason for the result could be attributed to the fact that in the short run government provides incentive to investors such as tax holiday, tax cut and lower tariff on imported machineries among others. These incentives reduce the frequency and volume of transaction by the investors in the foreign exchange market, thereby reducing volatility in the sub sector. In the long run, the coefficient of (FPI) is significant and positively correlated to exchange rate volatility. The finding could suggests that foreign investtors in Nigeria in the long run are exposed to importation cost probably imposed by increasing depreciation of machineries and other assets. This increases the activities and perhaps the volatility in the foreign exchange market. The short run result corroborates the findings of $[33,39$, $40]$ in Nigeria.

The ECM and long run model revealed significant negative effect between import (TIM) and exchange rate volatility in Nigeria. The result satisfies the a priori expectation as increase in exchange rate volatility would likely decrease importation activities due to increase importation cost both in the short and long run periods. The result agreed with the finding of [17] in Europe, [19] in USA and [20] for G-7 countries.

The coefficient of industrial capacity utilization (CUR) exhibited a positive significant impact on exchange rate volatility in both periods in Nigeria. The result satisfies the a priori expectation. Following the industrial policy of import substitution (1960-1985) and liberalization policy (1986 till date), most industries in Nigeria have strengthen their backward integration strategies. Therefore increase in exchange rate volatility serves as an incentive to boost domestic production and hence capacity utilization.

The liberalization policy period (D) has a significant negative influence on the exchange rate volatility in the long run. The finding shows that the exchange rate policies embedded in the liberalization period have negative significant influence on exchange rate volatility in Nigeria. In the short run the effect was positive but was not statistically significant. The result of the short run model agreed with the finding of Canales [30,31].

\section{Summary and Recommendations}

The study identified significant macroeconomic fundamentals that influence the exchange rate volatility in $\mathrm{Ni}$ geria. Macro-economic data from the period 1968 to 2010 were used in the study. Unit root on the specified variables confirmed the presence of co-integration among the series implying the presence of a long-run equilibrium relationship. The long run and ECM models for exchange rate volatility were estimated using the specified variables. The ECM error term had the appropriate sign and was statistically significant at $1 \%$ probability level indicating a quick convergence to equilibrium in each period, with intermediate adjustments captured by the differenced terms. The findings show that some key macroeconomic fundamentals in Nigeria's economy interact in each period to re-establish the long-run equilibrium in exchange rate volatility following a short-run random disturbance. The empirical result for the static or long run exchange rate volatility equation revealed that the industrial capacity utilization rate and foreign private investment have significant positive relationship with the exchange rate volatility the Nigeria. Whereas the total import, lending interest rate and liberalization policy period has a negative association with the exchange rate volatility. Also, the ECM model revealed that the index of exchange rate volatility in Nigeria in the short run decreases with increasing external reserves, lending interest rate of commercial banks, foreign private investment and total import. On the other hand, the exchange rate volatility rate increases with increasing inflation rate and industrial capacity utilization rate.

The findings call for appropriate short and long term policy packages that should focused on stabilization of the identified significant shifters of exchange rate volatility in the Nigeria's economy. Harmonization of transactions in the various foreign exchange markets in Nigeria should be a priority objective in the current exchange rate policy. This will reduce exchange rate policy diversion, enhanced monitoring and policy evaluation as well as increased the efficiency of the sub-sector.

\section{REFERENCES}

[1] K. Odubogun, "Institutional Reforms and the Management of Exchange Rate Policy in Nigeria," American Endurance Ride Conference Research Paper 36, African Economic Research Consortium, Nairobi, 1995.

[2] C. F. Obidegwu, "Adjustment Programs and Economic Change in Sub-Sahara Africa," Symposium on the Political Economy of Structural Adjustment Programs in Africa, Cornell University, Ithaca, 3 March 1990, under SPR Discussion Paper No. XX.

[3] M. Ndulo, "Exchange Rate Policy and the Auction System in Zambia, 1985-1987," A Final Report Presented to 
the African Economic Research Consortium Workshop, Nairobi, May 1990.

[4] T. A. Oyejide and O. Ogun, "Structural Adjustment and Exchange Rate Policy," In: A. Iwayemi, Ed., Macroeconomic Policy Issues in an Open Developing Economy: A Case Study of Nigeria, National Centre for Economic Management and Administration, Ibadan, 1992, pp. 307327.

[5] J. A. Frenkel and M. Goldstein, "Exchange Rate Volatility and Misalignment: Evaluating Some Proposals for Reform," In: Financial Market Volatility; a Symposium Sponsored by the Federal Reserve Bank of Kansas City, 1988, pp. 185-220.

[6] S. Edwards, "Real Exchange Rates, Devaluation and Adjustment: Exchange Rate Policy in Developing Countries," MIT Press, Cambridge, 1989.

[7] R. J. Caballero and V. Corbo, "The Effects of Real Exchange Rate Uncertainty on Exports: Empirical Evidence," The World Bank Economic Review, Vol. 13, No. 2, 1989, pp. 263-278. doi:10.1093/wber/3.2.263

[8] J. A. Cottani, D. F. Cavallo and M. S. Khan, "Real Exchange Rate Behaviour and Economic Performance in LDCs," Economic Development and Cultural Change, Vol. 39, No. 1, 1990, pp. 61-76.

[9] G. Benita and B. Lauterbach, "Policy Factors and Exchange Rate Volatility: Panel Data Verses a Specific Country Analysis," Research Unit, Foreign Exchange Activity Department, Bank of Israel, Jerusalem, 2004.

[10] M. B. Chowdhury, "The Determinants of Real Exchange Rate: Theory and Evidence from Papua Guinea," Asia Pacific School of Economics and Management Working Paper, 1999, pp. 99-92.

[11] E. D. Balogun, "Effects of Exchange Rate Policy on Bilateral Exports Trade of WAMZ Countries," Munich Personal RePec Archive (MPRA) Paper No. 6234, 2007.

[12] T. S. Osinubi and L. Amaghionyeodiwe, "Foreign Direct Investment and Exchange Rate Volatility in Nigeria," International Journal of Applied Econometrics and Quantitative Studies, Vol. 9, No. 2, 2009, pp. 83-116.

[13] B. Pinto, "Nigeria During and after the Oil Boom: A Policy Comparison with Indonesia," The World Bank Economic Review, Vol. 1, No. 3, 1987, pp. 419-445. doi:10.1093/wber/1.3.419

[14] A. Savvides, "Unanticipated Exchange Rate Variability and the Growth of International Trade," Welwirtschaftliches Archives, Vol. 128, No. 3, 1992, pp. 446-463. doi:10.1007/BF02707361

[15] T. Bollerslev, "Generalized Autoregressive Conditional Hetroscedasticity," Journal of Econometrics, Vol. 31, No. 3, 1986, pp. 307-327. doi:10.1016/0304-4076(86)90063-1

[16] R. Dornbusch, "Expectations and Exchange Rate Dynamics," The Journal of Political Economy, Vol. 84, No. 6, 1976, pp. 1161-1176. doi:10.1086/260506

[17] P. Gotur, "Effects of Exchange Rate Volatility on Trade: Some Further Evidence," IMF Staff Paper, Vol. 32, No. 3, 1985, pp. 475-512.

[18] D. O. Cushman, "US Bilateral Trade Flows and Exchange
Risk during the Floating Period," Journal of International Economics, Vol. 25, No. 3-4, 1988, pp. 317-330. doi:10.1016/0022-1996(88)90040-2

[19] A. C. Arize, "The Effects of Exchange Rate Volatility on US Imports: An Empirical Investigation," International Economic Journal, Vol. 12, No. 3, 1998, pp. 31-40. doi: $10.1080 / 10168739800000027$

[20] A. C. Arize and S. S. Shwiff, "Does Exchange-Rate Volatility Affect Import Flows in G-7 Countries? Evidence from Cointegration Models," Applied Economic, Vol. 30, No. 10, 1998, pp. 1269-1276. doi:10.1080/000368498324887

[21] S. Alam and Q. M. Ahmed, "Exchange Rate Volatility and Pakistan's Import Demand: An Application of Autoregressive Distributed Lag Model," International Research Journal of Finance and Economics, No. 48, 2010, pp. 7-22.

[22] World Bank, "Global Economic Prospects and the Developing Countries," Washington DC, 1984.

[23] N. Ndung'u, "Dynamics of the Inflationary Process in Kenya," University of Göteborg, Göteborg, 1993.

[24] M. Copelman and A. M. Wermer, "The Monetary Transmission Mechanism in Mexico," Working Paper, No. 25, Federal Reserve Board, Washington DC, 1996.

[25] P. Montiel, "Empirical Analysis of High-Inflation Episodes in Argentina, Brazil and Israel," IMF Staff Papers, Vol. 36, No. 3, 1989, pp. 527-549. doi:10.2307/3867046

[26] L. Kamas, "Monetary Policy and Inflation under the Crawling Peg: Some Evidence from VARs for Colombia," Journal of Development Economics, Vol. 46, No. 1, 1995, pp. 145-161. doi:10.1016/0304-3878(94)00052-E

[27] J. Jeong, "What Drives Exchange Rates? The Case of the Yen/Dollar Rate," Multinational Business Review, Vol. 8, No. 2, 2000, pp. 31-36.

[28] J. Cady and J. Gonzalez-Garcia, "The IMF's Reserve Template and Nominal Exchange Rate Volatility," International Monetary Fund Working Paper No. 274, 2006.

[29] J. Canales-Kriljenko and K. Habermeier, "Structural Factors Affecting Exchange Rate Volatility: A Cross-Section Study," International Monetary Fund Working Paper No. 147, 2004.

[30] E. Kočenda and J. Valachy, "Exchange Rate Volatility and Regime Change: A Visegrad Comparison," Journal of Comparative Economics, Vol. 34, No. 4, 2006, pp. 727-753. doi:10.1016/j.jce.2006.07.003

[31] J. Stancik, "Determinants of Exchange Rate Volatility: The Case of the New EU Members," CERGE-EI Discussion Paper Series No. 2006-158, 2006.

[32] H. K. M. Nowak and L. A. Ricci, "Can Higher Reserves Help Reduce Exchange Rate Volatility?" International Monetary Fund Working Paper No. 189, International Monetary Fund (IMF), Country Reports for Zimbabwe: 2000-2006, Washington DC, 2004.

[33] E. K. Oguneye, "Exchange Rate Volatility and Foreign Direct Investment in Sub Saharan Africa: Evidence from Nigeria and South Africa," A Paper Presented at the African Center for Economic Transformation in Ghana, 
2008.

[34] P. Korteweg, "Exchange Rate Policy, Monetary Policy and Real Exchange-Rate Variability," Essays in International Finance, No. 140, Pricenton, 1980.

[35] G. A. Khan, "The Output and Inflation Effects of Dollar Depreciation," Federal Reserve Bank of Kansas City, Research Working Paper 85-05, Federal Reserve Bank of Kansas City, Kansas City, 1989.

[36] I. A. Elbadawi, "Inflationary Process, Stabilization and the Role of Public Expenditure in Uganda," World Bank, Washington DC, 1990.

[37] G. A. Calvo, M. R. Carmen and A. V. Carlos, "Targeting the Real Exchange Rate: Theory and Evidence," IMF Working Paper WP/94/22, International Monetary Fund, Washington DC, 1994.

[38] F. O. Egwaikhide, N. C. Louis and O. F. Gabriel, "Exchange Rate Depreciation, Budget Deficit and Inflation-The Nigerian Experience," AERC Research Papers, No. 26, African Economic Research Consortium, Nairobi,
1994.

[39] E. Udoh and O. E. Festus, "Exchange Rate Volatility, Inflation Uncertainty and Foreign Direct Investment in Nigeria," BOJE: Botswana Journal of Economics, Vol. 57, No. 9-10, 2008, pp. 14-21.

[40] O. Alaba, "Exchange Rate Uncertainty and Foreign Direct Investment in Nigeria," A Paper Presented at the WIDER Conference on Sharing Global Prosperity, Helsinki, 6-7 September 2003.

[41] National Population Commission, "National Census Data for Nigeria," 2006.

[42] S. Johansen, "Statistical Analysis of Cointegration Vectors," Journal of Economic Dynamics and Control, Vol. 12, No. 2-3, 1988, pp. 231-254.

[43] S. Johansen and K. Juselius, "Maximum Likelihood Estimation and Inference on Cointegration-With Applications to the Demand for Money," Oxford Bulletin of Economics and Statistics, Vol. 52, No. 2, 1990, pp. 169-210. 